\title{
Traumatic Brain and Spinal Cord Fatalities Among High School and College Football Players — United States, 2005-2014
}

\author{
Kristen L. Kucera, $\mathrm{PhD}^{1}$; Rebecca K. Yau, PhD ${ }^{1,2}$; Johna Register-Mihalik, PhD ${ }^{3}$; Stephen W. Marshall, PhD ${ }^{2}$; Leah C. Thomas, MS ${ }^{1}$; Susanne Wolf ${ }^{1}$;
} Robert C. Cantu, MD4; Frederick O. Mueller, $\mathrm{PhD}^{1}$; Kevin M. Guskiewicz, $\mathrm{PhD}^{3}$

An estimated 1.1 million high school and 75,000 college athletes participate in tackle football annually in the United States. Football is a collision sport; traumatic injuries are frequent $(1,2)$, and can be fatal (3). This report updates the incidence and characteristics of deaths caused by traumatic brain injury and spinal cord injury (4) in high school and college football and presents illustrative case descriptions. Information was analyzed from the National Center for Catastrophic Sport Injury Research (NCCSIR). During 20052014 , a total of 28 deaths (2.8 deaths per year) from traumatic brain and spinal cord injuries occurred among high school (24 deaths) and college football players (four deaths) combined. Most deaths occurred during competitions and resulted from tackling or being tackled. All four of the college deaths and 14 (58\%) of the 24 high school deaths occurred during the last 5 years (2010-2014) of the 10-year study period. These findings support the need for continued surveillance and safety efforts (particularly during competition) to ensure proper tackling techniques, emergency planning for severe injuries, availability of medical care onsite during competitions, and assessment that it is safe to return to play following a concussion.

NCCSIR has been conducting catastrophic injury surveillance at the national level for high school and collegiate football since 1965 (5) and for all sports since 1982 (6). Deaths were identified through ongoing and systematic monitoring of public media sources (e.g., online search engines and news search engines) and individual reports from national and state-level organizations, clinicians, school authorities, and researchers. Once a death was identified, NCCSIR researchers contacted family members or school staff members to gather additional details. When possible, NCCSIR obtained medical examiner reports. Information was collected about the athlete's age and level of play; player position and activity; and injury type, medical care, and cause of death.

The events included in this study were defined as fatal traumatic brain and spinal cord injuries that occurred during a scheduled team activity (game, practice, or conditioning session) and were directly related to football-specific activities (e.g., tackling or being tackled). Each fatality report was manually reviewed for inclusion and classification. Fatality rates per 1 million players were calculated using National Federation of State High School Associations and National Collegiate Athletic Association participation statistics as the denominators. The causes and potential strategies to prevent these injuries were described in association with the 10 Haddon energy damage countermeasures (7). All procedures were reviewed and approved by the Institutional Review Board of the University of North Carolina at Chapel Hill.

During 2005-2014, a total of 24 high school and four college football-related traumatic brain and spinal cord injury fatalities were identified, for a combined average of 2.8 fatalities per year. Among the 24 high school fatalities (Table 1), 22 (92\%) involved head/brain injuries. All four college fatalities involved a brain injury. Subdural hematoma was the most common diagnosis for both high school and college fatalities ( $46 \%$ overall). Four (18\%) of the 22 high school players who died from brain injuries had sustained a concussion within 4 weeks of the event, and second impact syndrome (in which a second concussion occurs before a first concussion has properly healed, causing rapid and severe brain swelling) was implicated in three of these four events.

Among the 24 high school fatalities (Table 1), 20 (83\%) occurred during a game and during the regular season; 17 (71\%) involved tackling or being tackled. Among the four college fatalities, two occurred during a regular season game, and two occurred during spring football. The most common player positions among those fatally injured were running back ( $32 \%$ of players overall) and linebacker $(21 \%)$. Of the 28 deaths, head first/head down contact was identified in eight deaths. Six illustrative cases provide associations with the Haddon energy damage countermeasures and extensions to football recommendations for preventing traumatic brain and spinal cord fatalities (Table 2).

The average number of high school deaths per year was 2.4 (standard deviation $[S D]=2.2$ ) and ranged from zero to seven deaths annually. The average number of deaths among college players per year was $0.4(S D=0.7)$ and ranged from zero to two deaths annually. For 2 years (2007 and 2012) of the 10-year study period, no traumatic brain or spinal cord injury deaths were reported among either high school or college football players. Fatality rates over the study period were 5.96 fatalities per 1 million college football players $(95 \%$ confidence interval $[\mathrm{CI}]=0.12-11.81)$ and 2.18 fatalities per 1 million high school football players $(\mathrm{CI}=1.31-3.06)$ (Figure). All four of the college deaths and 14 (58\%) of the 24 high school deaths occurred during the last 5 years (2010-2014) of the 10-year study period. 


\section{Discussion}

The finding of an annual average of 2.8 brain and spinal cord injury deaths for high school and college football combined is consistent with a previous report of 3.1 brain injury fatalities annually during 1990-2010 (4). Also consistent with previous studies $(3,4)$, most brain and spinal cord injury deaths occurred during competition, among players at running back and linebacker positions, and as a result of tackling or being tackled.

Head first/head down contact was identified as contributing to eight of the 28 deaths. This emphasizes the importance of instruction in proper tackling techniques (both delivery and receipt of tackles) for all players, but particularly for running backs, linebackers, and defensive backs. A previous evaluation of football tackling programs among youth league football players indicated a reduction in concussions in practice and games when education of coaches was combined with practice contact restrictions (8), providing evidence that these programs might have a positive impact on reducing nonfatal head injuries among youth league players. However, it is unclear whether older players who learned high risk methods can be retrained in new techniques. Football is a collision sport played at high velocity, and players must act and react quickly. In such situations, new techniques might be difficult to deploy, resulting in players possibly reverting to past behaviors and reactions unless coaches routinely intervene to correct their technique.

The finding that $18 \%$ of high school players with fatal traumatic brain injuries had a concussion $<4$ weeks earlier is consistent with a previous study that found $16 \%$ of football players who died from traumatic brain injuries over a 20 -year period had a previous concussion within 30 days of death (4). This finding supports the importance of recognition, reporting, management, and adherence to recommended return-to-play protocols after a concussion. All 50 states and the District of Columbia currently have concussion education and safety laws in place that include appropriate medical evaluation by a trained medical professional, no same-day return to play, and return to play only after medical clearance. All laws include education for various stakeholders about concussion symptoms and management. However, for the laws to be effective, athletes must report their concussion symptoms, and medical professionals must be able to accurately assess symptom resolution and full recovery from the concussion before allowing an athlete to resume contact. The implementation and impact of these laws are an important area for future inquiry.

The cases described in this report illustrate the importance of emergency preparedness, recognition, and access to medical services. All schools should have written emergency action plans specific to their school and venue that are rehearsed annually by coaches and staff (9). The availability of medical
TABLE 1. Traumatic brain and spinal cord injury fatalities among high school and college football players, by selected characteristics United States, 2005-2014

\begin{tabular}{|c|c|c|c|}
\hline Characteristic & $\begin{array}{l}\text { College } \\
\text { No. (\%) }\end{array}$ & $\begin{array}{c}\text { High school } \\
\text { No. (\%) }\end{array}$ & $\begin{array}{l}\text { Total } \\
\text { No. (\%) }\end{array}$ \\
\hline \multicolumn{4}{|l|}{ Grade level } \\
\hline Freshman & $3(75)$ & $1(4)$ & $4(14)$ \\
\hline Sophomore & $0(0)$ & $3(13)$ & $3(11)$ \\
\hline Junior & $0(0)$ & $11(46)$ & $11(39)$ \\
\hline Senior & $1(25)$ & $7(29)$ & $8(29)$ \\
\hline Unknown & $0(0)$ & $2(8)$ & $2(7)$ \\
\hline \multicolumn{4}{|l|}{ Activity } \\
\hline Game & $2(50)$ & $20^{*}(83)$ & $22(79)$ \\
\hline Practice & $2(50)$ & $4(17)$ & $6(21)$ \\
\hline \multicolumn{4}{|l|}{ Season } \\
\hline Spring football & $2(50)$ & $0(0)$ & $2(7)$ \\
\hline Preseason & $1(25)$ & $3(13)$ & $4(14)$ \\
\hline Regular season & $1(25)$ & $20(83)$ & $21(75)$ \\
\hline Postseason & $0(0)$ & $1(4)$ & $1(4)$ \\
\hline \multicolumn{4}{|l|}{ Player action } \\
\hline Tackling & $1(25)$ & $9(38)$ & $10(36)$ \\
\hline Being tackled & $0(0)$ & $7(29)$ & $7(25)$ \\
\hline Being blocked & $1(25)$ & $4(17)$ & $5(18)$ \\
\hline Blocking & $0(0)$ & $1(4)$ & $1(4)$ \\
\hline General play & $2(50)$ & $2(8)$ & $4(14)$ \\
\hline Conditioning & $0(0)$ & $1(4)$ & $1(4)$ \\
\hline \multicolumn{4}{|l|}{ Suspected cause } \\
\hline Arteriovenous malformation & $0(0)$ & $1(4)$ & $1(4)$ \\
\hline Bleed & $0(0)$ & $1(4)$ & $1(4)$ \\
\hline Blood clot & $0(0)$ & $1(4)$ & $1(4)$ \\
\hline Cerebral swelling & $0(0)$ & $1(4)$ & $1(4)$ \\
\hline Fracture & $0(0)$ & $2(8)$ & $2(7)$ \\
\hline Hemorrhage & $0(0)$ & $2(8)$ & $2(7)$ \\
\hline Subdural hematoma & $2(50)$ & $11(46)$ & $13(46)$ \\
\hline Traumatic brain injury & $2(50)$ & $5(21)$ & $7(25)$ \\
\hline \multicolumn{4}{|l|}{ Body part injured } \\
\hline Head/Brain & $4(100)$ & $22(92)$ & $26(93)$ \\
\hline Spinal cord & $0(0)$ & $2(8)$ & $2(7)$ \\
\hline \multicolumn{4}{|l|}{ Position } \\
\hline Cornerback & $0(0)$ & $2(8)$ & $2(7)$ \\
\hline Defensive back & $1(25)$ & $2(8)$ & $3(11)$ \\
\hline Running back & $2(50)$ & $7(29)$ & $9(32)$ \\
\hline Running back/Linebacker & $0(0)$ & $1(4)$ & $1(4)$ \\
\hline Linebacker & $0(0)$ & $6(25)$ & $6(21)$ \\
\hline Defensive lineman & $1(25)$ & $1(4)$ & $2(7)$ \\
\hline Lineman & $0(0)$ & $1(4)$ & $1(4)$ \\
\hline Offensive lineman & $0(0)$ & $1(4)$ & $1(4)$ \\
\hline Safety & $0(0)$ & $2(8)$ & $2(7)$ \\
\hline Kickoff coverage & $0(0)$ & $1(4)$ & $1(4)$ \\
\hline Total & $4(100)$ & $24(100)$ & $28(100)$ \\
\hline
\end{tabular}

* One activity was a junior varsity scrimmage against a visiting team and was classified as a game.

professionals onsite who are trained to recognize and act in emergency situations is critical in catastrophic football injury events. Many schools employ certified athletic trainers, and for competitions, have emergency medical services onsite. However, nationally, $30 \%$ of public high schools do not have access to an athletic trainer, and $50 \%$ do not have athletic trainers present at practices (10). One of the deaths in this report occurred during a junior varsity football scrimmage 
TABLE 2. Descriptions of six illustrative cases of deaths from traumatic brain and spinal cord injury among high school and college football players and associated Haddon energy damage countermeasures* — United States, 2005-2014

\begin{tabular}{|c|c|c|c|c|c|}
\hline Year & $\begin{array}{l}\text { Player } \\
\text { action }\end{array}$ & Position & Activity & Narrative & Associated Haddon countermeasures \\
\hline 2005 & Blocking & $\begin{array}{l}\text { Kickoff } \\
\text { coverage }\end{array}$ & $\begin{array}{l}\text { Regular } \\
\text { season } \\
\text { game }\end{array}$ & $\begin{array}{l}\text { A high school player aged } 16 \text { years was injured at the end of } \\
\text { the second quarter of the game while blocking on a kickoff } \\
\text { return. The athlete lowered his helmet into the chest of } \\
\text { an opponent and appeared unconscious when he hit the } \\
\text { ground. He was immediately attended to by emergency } \\
\text { medical services and transported by ambulance to a } \\
\text { hospital. Surgery was performed to relieve pressure on the } \\
\text { brain, but the player never recovered consciousness. He died } \\
1 \text { week following the injury. Cause of death was a traumatic } \\
\text { brain injury. }\end{array}$ & $\begin{array}{l}\text { 1. Prevent the creation of the hazard: Ban head } \\
\text { first contact, regardless of intention, enforce } \\
\text { ban. } 4 \text {. Modify the rate or spatial distribution } \\
\text { of the hazard from its source: Decrease the } \\
\text { closing distance on kickoffs. } 8 \text {. Make what is to } \\
\text { be protected more resistant to damage from the } \\
\text { hazard: Provide universal education about proper } \\
\text { technique for blocking, strengthen neck muscles. }\end{array}$ \\
\hline 2008 & $\begin{array}{l}\text { Being } \\
\text { tackled }\end{array}$ & $\begin{array}{l}\text { Running } \\
\text { back }\end{array}$ & $\begin{array}{l}\text { Regular } \\
\text { season } \\
\text { game }\end{array}$ & $\begin{array}{l}\text { A high school player aged } 16 \text { years was injured during } \\
\text { the second quarter of the game. He collapsed on the } \\
\text { sideline after being tackled while carrying the ball. He was } \\
\text { transported to a hospital and died the next day. He had } \\
\text { received a concussion in practice } 2 \text { days before the game, } \\
\text { and it is unclear whether he had clearance from a physician } \\
\text { to return to play. Cause of death was a traumatic brain injury } \\
\text { resulting from second impact syndrome. }\end{array}$ & $\begin{array}{l}\text { 5. Separate by time or space the hazard from } \\
\text { that which can be protected: Return concussed } \\
\text { athletes to play only when symptom free, following } \\
\text { a graduated return to play progression, and when } \\
\text { fully healed (prevent second impact syndrome). }\end{array}$ \\
\hline 2010 & Tackling & $\begin{array}{l}\text { Defensive } \\
\text { back }\end{array}$ & $\begin{array}{l}\text { Spring } \\
\text { football }\end{array}$ & $\begin{array}{l}\text { A college player aged } 21 \text { years was injured during a spring } \\
\text { season game. He was injured on the last play of the game } \\
\text { while making a tackle and taking a blow to the head. } \\
\text { He suffered an acute subdural hematoma. He walked } \\
\text { off the field, but began vomiting on the sideline. He was } \\
\text { immediately attended to by the athletic trainer, and } \\
\text { emergency medical services were summoned. He was taken } \\
\text { to a regional hospital and flown by helicopter to a trauma } \\
\text { center, where he later died. }\end{array}$ & $\begin{array}{l}\text { 1. (see above) } 2 \text {. Reduce the amount of the hazard: } \\
\text { Reduce the number and magnitude of head } \\
\text { impacts in spring season events. } 8 \text {. (see above) }\end{array}$ \\
\hline 2011 & $\begin{array}{l}\text { General } \\
\text { play }\end{array}$ & $\begin{array}{l}\text { Running } \\
\text { back }\end{array}$ & $\begin{array}{c}\text { Preseason } \\
\text { practice }\end{array}$ & $\begin{array}{l}\text { A college player aged } 22 \text { years was participating in football } \\
\text { drills during practice when he collapsed. He was taken to a } \\
\text { regional medical center and flown by helicopter to a trauma } \\
\text { center, where a diagnosis was made of severe head trauma } \\
\text { and swelling of the brain. He died several days later after } \\
\text { multiple surgeries. Reports indicated that his forehead had } \\
\text { been bleeding for } 2 \text { days prior as a result of a previously } \\
\text { sustained head injury. He returned to practice despite } \\
\text { complaints of a headache and dizziness. }\end{array}$ & $\begin{array}{l}\text { 2. (see above) } 5 \text {. (see above) } 10 \text {. Stabilize, repair } \\
\text { and rehabilitate the damage or injured person: } \\
\text { Provide advanced trauma care. }\end{array}$ \\
\hline 2014 & Tackling & Lineman & $\begin{array}{l}\text { Regular } \\
\text { season } \\
\text { game }\end{array}$ & $\begin{array}{l}\text { A high school football player who was a junior sustained } \\
\text { an injury during a game with the possibility of head- } \\
\text { on-head contact during a kick return. He walked off } \\
\text { the field at halftime and shortly afterward collapsed } \\
\text { and lost consciousness. Police onsite called emergency } \\
\text { medical services; there was no ambulance at the game. } \\
\text { Cardiopulmonary resuscitation was administered upon the } \\
\text { arrival of the emergency medical services unit, and he was } \\
\text { transported by ambulance to a local hospital } 18 \text { miles away } \\
\text { when he was unable to be stabilized for helicopter transport. } \\
\text { He died shortly afterward at the hospital. Preliminary cause } \\
\text { of death was blunt force trauma to the head. }\end{array}$ & $\begin{array}{l}\text { 1. (see above) 8. (see above) 9. Move rapidly } \\
\text { to detect and evaluate the damage that has } \\
\text { occurred and counter its continuation and } \\
\text { extension: Implement an emergency action plan } \\
\text { and provide emergency medical services onsite for } \\
\text { games. 10. (see above) }\end{array}$ \\
\hline 2013 & Tackling & Cornerback & $\begin{array}{l}\text { Regular } \\
\text { season } \\
\text { game }\end{array}$ & $\begin{array}{l}\text { A high school player aged } 16 \text { years collapsed after making a } \\
\text { "routine" tackle during a junior varsity scrimmage against a } \\
\text { visiting team. Witnesses to the event reported that his head } \\
\text { was up when he made the tackle and that his head hit his } \\
\text { opponent's chest. Coaches and adults responded and found } \\
\text { he was not breathing. They telephoned emergency medical } \\
\text { services, which took } 15 \text { minutes to arrive at the suburban } \\
\text { school. Emergency medical services began cardiopulmonary } \\
\text { resuscitation and transported the player to the hospital, } \\
\text { where he died shortly afterward. Autopsy confirmed C-3 } \\
\text { cervical fracture from blunt force head and neck trauma. }\end{array}$ & 8. (see above) 9. (see above) 10. (see above) \\
\hline
\end{tabular}

\footnotetext{
* Haddon W Jr. Energy damage and the ten countermeasure strategies. J Trauma 1973;13:321-31.
} 
FIGURE. Fatality rates from traumatic brain and spinal cord injuries among high school and college football players - United States, 2005-2014

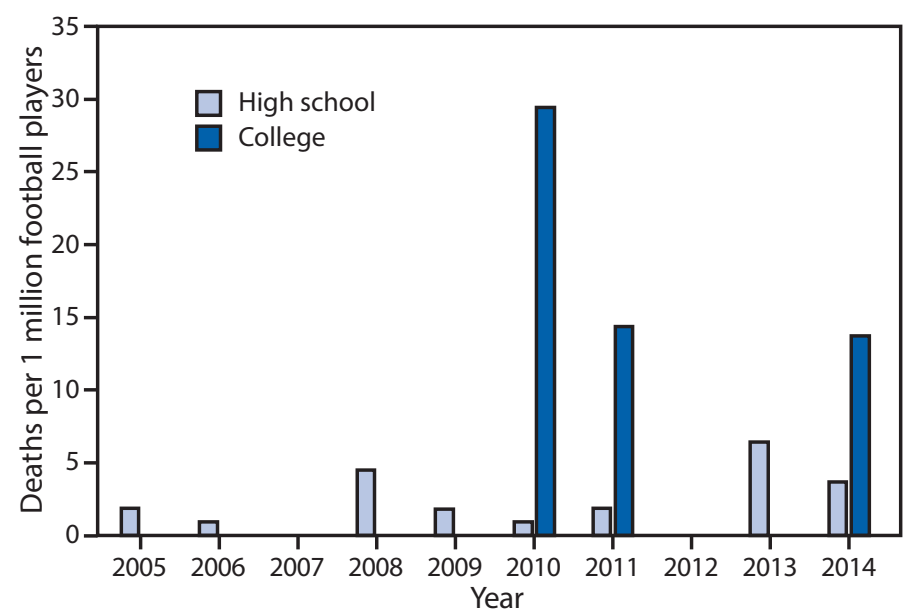

when emergency medical services were not onsite and arrival of emergency medical services took 15 minutes because of traffic. Current best practices include access to athletic trainers for practices and competition and maintaining emergency medical services onsite during competitions (9).

The findings in this report are subject to at least four limitations. First, most events were captured through publicly available media sources, and it is possible that some football deaths were missed. Second, football participation numbers are representative of National Federation of State High School Associations and National Collegiate Athletic Association-affiliated schools and likely underestimate the actual number of football participants. Third, whenever possible, medical diagnoses and medical examiner report causes of death were used, however, the exact diagnosis was unknown for seven of the traumatic brain injury deaths. Information availability might be hampered by the sensitivity surrounding a fatal event, potential litigation, and inability to talk with persons involved. Finally, public interest and media attention about sport-related deaths and traumatic brain injuries increased during the study period, and it is unknown how this might have affected the identification of fatal injuries over time.

These findings support continued surveillance and safety efforts to ensure proper tackling techniques, emergency planning, and medical care, particularly during competition, and adherence to protocols for safe return-to-play after a concussion. These measures will also reduce the risk for concussion and improve treatment and management after a concussion is sustained. CDC provides emergency action plan templates and guidance (https://www.cdc.gov/niosh/

\section{Summary}

What is already known about this topic?

Fatalities resulting from catastrophic brain and spinal cord injuries occur infrequently among high school and college football players.

What is added by this report?

During 2005-2014, a total of 28 traumatic brain and spinal cord injury deaths in high school and college football were identified (2.8 deaths per year). The most common playing positions of those fatally injured were running back and linebacker. Approximately $18 \%$ of identified high school brain injury deaths were preceded by an earlier concussion, which might have led to second impact syndrome.

What are the implications for public health practice?

Implementing enhanced safety measures to prevent fatalities from catastrophic brain and spinal cord injuries among high school and college football players has the potential to reduce the number of these fatalities. Continued surveillance is important to monitor the circumstances of these deaths and develop risk scenarios to improve prevention measures.

docs/2004-101/emrgact/emrgact 1.html) and information about concussions through the CDC HEADS UP program (https://www.cdc.gov/headsup/). Information on state laws related to concussions is available at https://www.ncsl.org/ research/health/traumatic-brain-injury-legislation.aspx. Catastrophic sport injuries can be reported to the National Center for Catastrophic Sport Injury Research at http:// nccsir.unc.edu/.

\section{Acknowledgments}

Julie Gilchrist, MD, National Center for Injury Prevention and Control, CDC; R. Dawn Comstock, PhD, Douglas J. Casa, $\mathrm{PhD}$, Tom P. Dompier, PhD, Jonathan A. Drezner, MD, Zackary Y. Kerr, PhD, David Klossner, PhD, Rebecca L. Stearns, PhD, Consortium for Catastrophic Injury Monitoring in Sport. The National Center for Catastrophic Sport Injury Research is funded by the following organizations: the American Football Coaches Association, the National Athletic Trainers' Association, the National Collegiate Athletic Association, the National Federation of State High School Associations, the National Operating Committee on Standards for Athletic Equipment, and the American Medical Society for Sports Medicine.

\footnotetext{
${ }^{1}$ National Center for Catastrophic Sport Injury Research, Department of Exercise \& Sport Science, University of North Carolina at Chapel Hill; ${ }^{2}$ Injury Prevention Research Center, University of North Carolina at Chapel Hill; ${ }^{3}$ Matthew Gfeller Sport-Related Traumatic Brain Injury Research Center, Department of Exercise \& Sport Science, University of North Carolina at Chapel Hill; ${ }^{4}$ Emerson Hospital and Boston University, Massachusetts.

Corresponding author: Kristen Kucera, kkucera@email.unc.edu, 919-962-6228.
} 


\section{References}

1. Dompier TP, Kerr ZY, Marshall SW, et al. Incidence of concussion during practice and games in youth, high school, and collegiate American football players. JAMA Pediatr 2015;169:659-65. http://dx.doi.org/10.1001/ jamapediatrics.2015.0210

2. Kerr ZY, Collins CL, Fields SK, Comstock RD. Epidemiology of player-player contact injuries among US high school athletes, 2005-2009. Clin Pediatr (Phila) 2011;50:594-603. http://dx.doi.org/10.1177/0009922810390513

3. Cantu RC, Mueller FO. Brain injury-related fatalities in American football, 1945-1999. Neurosurgery 2003;52:846-53. http://dx.doi. org/10.1227/01.NEU.0000053210.76063.E4

4. Boden BP, Breit I, Beachler JA, Williams A, Mueller FO. Fatalities in high school and college football players. Am J Sports Med 2013;41:1108-16. http://dx.doi.org/10.1177/0363546513478572

5. Mueller FO, Blyth CS. Fatalities from head and cervical spine injuries occurring in tackle football: 40 years' experience. Clin Sports Med 1987;6:185-96.
6. Cantu RC, Mueller FO. The prevention of catastrophic head and spine injuries in high school and college sports. Br J Sports Med 2009;43:981-6. http://dx.doi.org/10.1136/bjsm.2009.067728

7. Haddon W Jr. Energy damage and the ten countermeasure strategies. J Trauma 1973;13:321-31. http://dx.doi.org/10.1097/00005373-197304000-00011

8. Kerr ZY, Yeargin S, Valovich McLeod TC, et al. Comprehensive coach education and practice contact restriction guidelines result in lower injury rates in youth American football. Orthop J Sports Med 2015;3:2325967115594578. http://dx.doi.org/10.1177/2325967115594578

9. Casa DJ, Guskiewicz KM, Anderson SA, et al. National athletic trainers' association position statement: preventing sudden death in sports. J Athl Train 2012;47:96-118.

10. Pryor RR, Casa DJ, Vandermark LW, et al. Athletic training services in public secondary schools: a benchmark study. J Athl Train 2015;50:156-62. http://dx.doi.org/10.4085/1062-6050-50.2.03 